In accordance with the national program "Education" ("Ukraine of the 21st Century") (1993), one of the principles of reforming the educational system in Ukraine was its humanization. The humanization process, in particular, was promoted by the adoption of the Law of Ukraine "On the bodies and services for the affairs of adolescents and special institutions for adolescents" (1995). According to this document, the special school not only changed its name, but also received new functional tasks. The idea of "rehabilitating of the offender" changed the concept of creating such living conditions for them, which, although in some way limit the adolescent's rights, do contribute to the development of their personality.

Key words: reforming school education, institutions of general secondary education, juvenile offenders, compulsory measures of educational nature, school of social rehabilitation, special general education school for children and adolescents who need special conditions of education.

DOI: 10.32626/2309-9763.2019-26-1.14-18

Олена Березкіна, Оксана Височин Olena Berezkina, Oksana Vysochyn

\author{
МОНІТОРИНГ ДОСЛІДЖЕННЯ ВПЛИВУ ОРГАНІЗАЦІЇ \\ ЗДОРОВ'ЯЗБЕРІГАЛЬНОЇ ДІЯЛЬНОСТІ ЗАКЛАДУ ВИЩОЇ ОСВІТИ \\ НА ФОРМУВАННЯ ЗДОРОВОГО СПОСОБУ ЖИТТЯ ПІДЛІТКІВ
}

\title{
MONITORING OF THE RESEARCH OF THE INFLUENCE OF HEALTH- PRESERVING ACTIVITIES ORGANISATION OF HIGHER EDUCATION INSTITUTION ON THE FORMATION OF TEENAGERS' HEALTHY LIFESTYLE
}

\begin{abstract}
Автори статті констатують, що з огляду на стан здоров'я зростаючого покоління стає зрозумілою деяка обмеженість традиційної організації освітнього процесу та ії згубний вплив на здоров'я студентів. Узв'язку з иим актуалізується завдання пошуку ефективних освітніх технологій, у яких збереження здоров'я студентів є пріоритетним. Науково облрунтоване розгортання процесів розробки й упровадження технологій, спрямованих назбереження здоров'я студентів, вимагає теоретичного обгрунтування сутності поняття здоров'язбереження людини. У зв'язку з постійними соціально-економічними та природними змінами, що відбуваються у світі, діяльність зі збереження, зміцнення та формування здоров'я молодого покоління вимагає своєчасної корекиіі.
\end{abstract}

Ключові слова: заклади вищої освіти, освітній процес, здоров'я підлітків, здоров'язберігальна діяльність освіти, педагоги.

Стан здоров’я є показником духовного, соціально-економічного й людино-біологічного добробуту населення, рівня цивілізованості країни. Гуманізація освіти вимагає якісно нового підходу до потреб людини, формування стійких мотивацій до здорового способу життя, позитивної соціальної поведінки. Державні національні програми “Діти України” та “Освіта” (Україна XXI століття), “Національна доктрина розвитку освіти” одним із головних завдань закладів освіти визначають збереження і зміцнення фізичного, психічного, соціального та морального здоров'я молоді, формування в них умінь і навичок здорового способу життя. Тому кожна освітня установа сьогодні шукає свій шлях змін у просторі покращення якості освіти та виховання [1, с. 23].

Для сучасних досліджень здоров'язберігальних проблем характерний різноаспектний підхід. Філософський та соціальний напрями відображено в працях А. Бойко, Н. Гундарева,

(c) Олена Березкіна, Оксана Височин, 2019 
В. Крюкова, Ю. Лисицина, О. Сахно. Напрями валеологічної обізнаності описано в працях Т. Бойченко, Є. Буліча, М. Гамезо, В. Горащука, Т. Кириченка, С. Юрочкіної. Нові соціально-педагогічні здоров'язберігальні технології пропонують В. Беспалько, П. Гусак, Н. Заверико, Н. Зимівець, В. Петрович, Л. Сущенко та інші.

Також поділяються думки багатьох педагогів-класиків (В. Бехтерева, П. Лесгафта, Г. Песталоцці, С. Френе, Р. Штайнера та ін.), так і сучасних науковців (В. Бобрицької, О. Савченко, Г. Серікова, Т. Савустьяненко та ін.), що розв'язання проблеми забезпечення збереження й формування здоров'я людини лежить у площині побудови освітнього процесу відповідно до цілей і принципів гуманістичної освіти.

Тому важливим завданням освітньої установи є збереження здоров'я та його зміцнення, і соціально-педагогічне забезпечення відіграє в цьому велику роль та в умовах сьогодення повинно постійно змінюватися та вдосконалюватися.

Мета дослідження - дослідити здоров'язберігальну діяльність закладу вищої освіти та визначити основні теоретико-методологічні засади соціально-педагогічного забезпечення освітньої установи щодо збереження здоров’я підлітків.

Соціально-політичні й економічні зміни, що відбуваються у нашій країні, поставили педагогів перед гострою необхідністю критичної переоцінки науково-теоретичних основ системи виховання, орієнтованості їх на формування духовних потреб, здорових звичок, фізичного загартування та збереження здоров'я підлітків.

Проблема здоров’язбереження та формування здорового способу життя належить до вічних в історії людства. Аналіз науково-методичних джерел свідчить про те, що для оптимізації процесу здоров'язбереження молоді та підлітків фізичне виховання повинно займати у закладах освіти одне із провідних місць.

Проведений аналіз наукової літератури з проблеми дослідження дозволяє зробити висновки про багатоаспектність, багатогалузевий і міждисциплінарний характер. Відтак, завдання нашого дослідження потребує використання деяких наукових підходів.

Найбільш важливим $€$ концепція контекстного, суб’єкт-діяльнісного підходу до навчання та виховання, відповідно до якого навчальна діяльність усіх учасників освітнього процесу щодо оволодіння знаннями, вміннями та навичками має бути адекватною їх практичному застосуванню у професійній діяльності, коли сама навчальна діяльність має моделювати на практично-теоретичному рівні цю професійну діяльність. Такий підхід у площині здорового способу життя реалізується як діяльнісний підхід. Так, низка науковців визначають проблему формування здорового способу життя в контексті діяльнісного підходу - оздоровлення умов життя, збереження і зміцнення здоров’я в процесі життєдіяльності. Зокрема, на думку B.О. Петькова та О.М. Кобцева, здоровий спосіб життя формується в процесі діяльності активності самої особистості, що забезпечує відносну єдність і узгодженість основних рівнів життя людини: соціального, психічного і фізичного [6, с. 67-70].

У зв’язку з цим I.M. Мельничук виокремлює ціннісні орієнтації особистості щодо здорового способу життя, а саме: "психологічна установка на розумну організацію власного життя, яка максимальною мірою зберігає та зміцнює здоров’я, що є основою забезпечення нормального розвитку та життєдіяльності особистості" [5, с. 5-7].

Відтак, тут важливим $€$ свідомий вибір здорового способу життя студентами, що зумовлюється свідомим ставленням особистості до власного здоров'я та розуміння його значущості для людини та суспільства.

Також інтерес до проблеми збереження здоров'я з боку вчених викликаний не лише погіршенням фізичного, психічного і морального здоров'я молоді, але й новою ідеєю - ідеєю відродження України.

За останні роки в Україні зроблено значні кроки на шляху створення умов для формування здоров'я людини через освіту. Законами України, державними національними програмами 
визначено необхідність розв'язання найважливіших завдань сучасної освіти, спрямованих на здоровий інтелектуальний, соціальний, фізичний розвиток особистості [2; 3; 4].

Водночас констатуємо, що незважаючи на значну увагу держави, науковців щодо питань здоров’я зростаючого покоління, досі ця проблема не розв’язана належним чином. Достатньо сказати, що частка здорової молоді в Україні, за різними даними, коливається від 4 до 10 \%. При цьому за останні роки спостерігається тенденція погіршення стану здоров'я студентів. I значна частина захворювань дітей і молоді має так звану дидактогенну природу, викликана або спровокована освітньою установою.

На жаль, завдання профілактики і збереження здоров’я підлітків уважається вторинною щодо базового освітнього процесу, що різко знижує ефективність роботи освітньої установи щодо збереження і зміцнення здоров'я студентів і педагогів. Можна констатувати, що, по-перше, робота зі збереження здоров'я в освітній установі, як правило, має суто медичну основу, тому що виходить з ідеї “лікування хвороб”; по-друге, педагогічною теорією іпрактикою не розроблені технології перекладу знань про здоров’я і здоровий спосіб життя на поведінковий рівень; по-третє, немає переконливих критеріїв оцінки ефективності процесу оздоровлення підлітків, незважаючи на те, що здоров’я неухильно погіршується.

3 огляду на стан здоров'я зростаючого покоління стає зрозумілою деяка обмеженість традиційної системи організації освітнього процесу та ії згубний вплив на здоров'я студентів. У зв'язку з цим актуалізується завдання пошуку ефективних освітніх технологій, у яких збереження здоров'я студентів $€$ пріоритетним. Науково вивірене розгортання процесів розробки й упровадження технологій, спрямованих на збереження здоров'я молоді, вимагає теоретичного обгрунтування сутності поняття здоров’язбереження людини.

У зв’язку з постійними соціально-економічними та природними змінами, що відбуваються у світі, діяльність зі збереження, зміцнення та формування здоров’я молодого покоління вимагає своєчасної корекції.

Дослідження було спрямоване на реалізацію порівняльного аналізу роботи психологів і кураторів та співставлення результатів із опитуванням студентів, тобто дослідити соціально-педагогічне забезпечення здоров'язберігальної діяльністі закладу вищої освіти.

Дослідження соціально-педагогічного забезпечення здоров'язберігальної діяльності підлітків проводилось за розробленими анкетами для психологів, кураторів та студентів Полтавського коледжу нафти і газу Полтавського національного технічного університету імені Юрія Кондратюка. Кількість опитаних психологів - 5 осіб, кураторів груп - 5 осіб, студентів 66 осіб. Анкетування проводилось анонімно, в кожній анкеті було по 10 запитань, на які були варіанти відповідей або пропонувалось дати свою відповідь.

Для початку варто дізнатись, яке значення вкладають студенти закладу в поняття “здоров'я”. Таке запитання було відкритим, тому буде виокремлено лише найбільш популярні варіанти відповідей та їх якісний аналіз. Отже, всі респонденти визначають “здоров'я” як невід’ємну складову нормальної життєдіяльності, без якого неможливо обійтися.

Студентам також було запропоновано оцінити стан власного здоров'я і тим самим виявити, який відсоток підлітків уважає, що їхнє здоров'я погіршується. Результати показали, що переважна більшість уважає відмінний (19\%) та добрий (23\%) стан свого здоров'я. А от задовільним та незадовільним станом власного здоров'я вважає 7\% та 11\% відповідно. Ще досить не малий відсоток (12\%) чітко не змогли оцінити стан власного здоров'я.

Опитування про значення здоров'я у процесі навчання показало, що значна більшість респондентів визначають значення здоров'я як першочергове: $63 \%$ психологів, 46\% кураторів та 44\% студентів. Також психологи (11\%), куратори (19\%) та студенти (22\%) дали відповідь, що здоров'я має другорядне значення в освітньому процесі і приблизно по 17\% респондентів у кожній групі опитаних виникли труднощі з відповіддю на таке запитання та 15\% студентів не вважає, що стан здоров'я впливає на процес їхнього навчання. 
Рівень та масштаби проблеми здоров'я дітей наштовхують на припущення, що велика кількість спеціалістів та самих студентів просто не знає про таку проблему. Але анкетування спростовує таке припущення, тому що психологи і куратори, відповідаючи на питання, чи знають вони про проблему погіршення здоров'я студентів, відповіли “так”.

Отже, проаналізувавши результати, можна сказати, що в коледжі здійснюється робота зі збереження здоров’я студентів та профілактика його погіршення.

Підсумовуючи проведене дослідження, варто дати оцінку сьогоденної роботи закладу вищої освіти щодо здоров’язбереження, а саме роботі психолога та його вкладу у цю роботу.

Формування у підростаючого покоління мотивації до здорового способу життя потребує системної комплексної роботи, яка спрямована на діагностику, корекцію функціонального, психофізіологічного та духовно-морального стану людини. Сформовані знання, вміння й навички забезпечують необхідний рівень працездатності, моралі та духовності кожного, й, у першу чергу, - дитини. Вони дають змогу зберегти та зміцнити здоров'я та сприяють свідомому ставленню до власного здоров'я. Тому було розроблене соціально-педагогічне забезпечення здоров'язберігальної діяльності студентів закладу освіти.

Моніторинг стану здоров'я студентів та пов'язаних з ними процесів за допомогою анкетування та тестування, що дає змогу контролювати стан здоров'я та робити висновки щодо ефективності здоров’язберігальної діяльності закладу освіти, а також на основі цього виявляти недоліки та змінювати їх, покращувати програми здоров’язбереження студентів коледжу.

Дослідження стану здоров'я студентів та діяльності закладу освіти у напрямі збереження і зміцнення здоров'я молоді свідчить про необхідність активного використання здоров'язберігальних технологій в освітньому процесі. Зміст здоров'язберігальних технологій різноманітний і включає заходи, які спрямовані на збереження основних складових здоров'я студентів, головним чином на фізичне здоров'я. Ефективність використання здоров'язберігальних технологій залежить від професійної підготовленості педагогів, а також від взаємодії між педагогами, студентами і батьками [7, с. 13].

Використання результатів цих досліджень дає змогу спроектувати відповідну програму соціально-педагогічної технології з формування здорового способу життя, грунтуючись на інтегративному та особистісно зорієнтованому підходах до визначення змісту освіти і виховання.

Зазначене вище дозволяє дійти важливого висновку про те, що назріла необхідність розробити уніфіковане міждисциплінарне предметне поле освітньої програми, у межах якої знаходили 6 відображення проблеми здорового способу життя, збереження здоров'я та його зміцнення як у контексті формувального, так і діагностичного спрямувань. Відтак, процес здоров'язбереження студентської молоді постає інтегрованим, таким, що має забезпечувати інтеграцію природничих та гуманітарних знань.

Певними предметно-методичними підвалинами може слугувати програма соціально-педагогічного забезпечення здоров'язберігальної діяльності студентів освітньої установи, яка постає інтегративним у силу єдиного актуального завдання (подолання згубних звичок та пропаганда на цій основі здорового способу життя), яке спрямовується на всі верстви населення, у тому числі на підлітків.

Проведений аналіз наукової літератури з проблем дослідження дозволяє дійти висновку про багатоаспектність, багатогалузевий, міждисциплінарний характер проблеми збереження здоров'я молоді та його зміцнення під час навчально-виховного процесу закладу освіти.

Створення здоров'язберігального освітнього середовища $є$ головною передумовою зміцнення здоров'я студентської молоді, що передбачає раціональне планування навчального навантаження на студента; вміле поєднання іiі рухової активності з розумовою діяльністю, організацію збалансованого харчування, що широко описано і вивчено у низці наукових праць та літературі. 
Отже, в наукових дослідженнях із педагогіки і психології представлений достатній методологічний і теоретичний потенціал для вивчення проблеми здоров'язбереження та формування здорового способу життя у студентів закладу освіти, організація здоров'язберігальної діяльності.

Використання результатів цих досліджень дає змогу спроектувати відповідну програму соціально-педагогічної технології з формування здорового способу життя, грунтуючись на інтегративному та особистісно зорієнтованому підходах до визначення змісту освіти і виховання.

\section{Список використаних джерел}

1. Демінська Л.О. Аналіз змісту і умов використання здоров'язберігаючих технологій у системі загальноосвітніх шкіл // Педагогіка, психологія та медико-біологічні проблеми фізичного виховання і спорту. 2010. № 11. С. 23-26.

2. Закон України “Про освіту" // Початкова школа. 1999. №8. С. 1-11.

3. Концепція виховання дітей та молоді у національній системі освіти //Інформаційний збірник МОН України. 2006. №10. С. 3-16.

4. Концепція загальнодержавної цільової соціальної програми “Здорова нація” на 2009-2013 роки. Розпорядження Кабінету Міністрів України від 21 травня 2008 р. №731-р Концепція неперервної валеологічної освіти в Україні //Шкільний курс "Валеологія" : 36. матеріалів. К. : Освіта, 2009. 94 с.

5. Мельничук I.M. Теоретичні основи здоров’язбереження // Філософія, методологія, психолого-педагогічні аспекти формування культури здоров'язбереження : збірник тез науково-методологічного семінару кафедри філософії та суспільних дисциплін ТДМУ імені І.Я. Горбачевського. Тернопіль : Вектор, 2013. С. 5-7.

6. Петьков В.А., Кобцева О.Н. Проектирование здоровьесберегающей деятельности образовательного учреждения // Культура и физическое здоровье. 2009. №6. С. 67-70.

7. Чернишов O.I. Стратегічні напрями здоров'язбереження в освіті // Здоров’я через освіту. Матеріали міжгалузевої регіональної науково-практичної конференції, 22 квітня 2009 року. Т. 1. С. 13.

The article studies the influence of health-preserving activities organisation on the formation of teenagers' healthy lifestyle within the higher education institution. The authors of the article state that traditional organization of the educational process has a harmful effect on young generation's health. In this regard, the search for effective educational technologies to improve students' health is a vital task of modern education. The scientifically verified development and implementation of technologies aimed at preserving students' health require the theoretical substantiation of the concept of human's health-preservation. Due to the constant socio-economic and natural changes taking place in the world, the process of preserving, strengthening and forming of young generation's health requires changes and correction.

Health-preserving technologies imply the measures aimed at preserving the basic components of students' physical health. The effectiveness of using health-preserving technologies depends on the teachers' professional preparedness, as well as on the interaction between teachers, students and parents.

The research shows the necessity to develop a unified, interdisciplinary subject field of the curriculum, reflecting the problem of healthy lifestyle, preservation and strengthening of health in the context of forming and diagnostic directions. The process of student youth's health-preservation is an integrated one, integrating natural and humanitarian knowledge.

The results of this study enable to model the program of social-pedagogical technology on healthy lifestyle formation based on the integrative and personally-oriented approaches to the definition of the content of education and upbringing.

Key words: higher education institution, educational process, teenagers' health, health-preserving activities of education, teachers. 